\title{
Drought propagation in the hydrological cycle in a semiarid region: a case study in the Bilate catchment, Ethiopia
}

\author{
Buruk Kitachew Wossenyeleh ${ }^{1,2}$ (D) Ayalew Shura Kasa $^{3} \cdot$ Boud Verbeiren $^{2} \cdot$ Marijke Huysmans $^{1,2}$
}

Received: 5 April 2021 / Accepted: 18 January 2022 / Published online: 18 February 2022

(C) The Author(s) 2022

\begin{abstract}
Drought is a temporal decrease in water availability and occurs in all climatic regions. Droughts propagate through the hydrological cycle, e.g., meteorological drought propagates to groundwater recharge drought. This research investigated drought propagation in the hydrological cycle in a semiarid context. Meteorological drought severity was determined using a standardized precipitation index (SPI). A variable threshold method and standardized groundwater index (SGI) was implemented to investigate groundwater recharge drought. Comparing meteorological drought (SPI) and groundwater drought (SGI) helps to assess drought propagation in the hydrological cycle. For drought analysis, time-series of rainfall and groundwater recharge needs to be available with high spatial and temporal resolution. Therefore, for this study, daily rainfall measurements were collected from 11 meteorological stations, and water balance modeling was used to estimate temporally and spatially distributed groundwater recharge. This research was carried out in the Bilate River catchment in the Rift Valley basin of Ethiopia. Results show that meteorological droughts were observed before every groundwater recharge drought and they propagate to groundwater recharge drought. Furthermore, analysis of the drought propagation indicates that not all meteorological droughts are propagated. The analysis also shows that a combination of mild to severe meteorological droughts can propagate to groundwater recharge and result in a major groundwater-recharge drought event.
\end{abstract}

Keywords Groundwater recharge $\cdot$ Groundwater drought $\cdot$ Meteorological drought $\cdot$ Drought propagation $\cdot$ Ethiopia

\section{Introduction}

Droughts are regional, and regional climatic parameters govern their occurrence. Semiarid environments regularly experience low water availability since the mean annual potential evapotranspiration is $2-5$ times the mean annual precipitation (Pandey and Ramasastri 2002; Ponce et al. 2000; Schwabe et al. 2013a; Stahl and Hisdal 2004; WMO 1975). In consequence, droughts in semiarid regions may have a large impact on the poverty rate, health, ecosystem services, and economic development (Schwabe et al. 2013b).

Buruk Kitachew Wossenyeleh burukkitachew.wossenyeleh@kuleuven.be; bkwdae@gmail.com

1 Department of Earth and Environmental Sciences, KU Leuven University, Leuven, Belgium

2 Department of Hydrology and Hydraulic Engineering, Vrije Universiteit Brussel, Brussels, Belgium

3 Department of Water Resources and Irrigation Engineering, Hawassa University, Hawassa, Ethiopia
During a meteorological drought period, water scarcity may affect agricultural activities, leading to reductions in agricultural production and productivity, i.e., agricultural drought is developed (Das et al. 2003; Pandey et al. 2008; Todmal 2019). In semiarid regions, particularly in Ethiopia, meteorological drought, agricultural drought, and food security have been studied; however, the impact of drought on groundwater resources, i.e., groundwater drought, has not received much attention.

Regardless of its surface-water and groundwater resource potential, Ethiopia has been facing drought at an increasing frequency throughout the past decades (Edossa et al. 2010; Zewdie 1994). Severe drought has been recorded in the country throughout human history. The drought frequency used to be once in 5 years in Ethiopia based on the recent records (Edossa et al. 2010). However, all these studies are based on meteorological, surface water, or agricultural data; therefore, the country needs to investigate its potential for groundwater resources due to its reliability, particularly in periods of drought.

The water security of the country during meteorological, hydrological (only surface water), and agricultural drought is 
highly dependent on groundwater availability, access to groundwater, and demand for groundwater (MacDonald et al. 2001); furthermore, Godfrey and Hailemichael (2017) and Thomas et al. (2019) indicated that groundwater is the only available water resource in drought-affected parts of the country. Hence, managing and developing groundwater is an essential option for the sustainable development of the country; however, studies about groundwater resource management related to drought propagation and characterization have not been conducted for the study area. Consequently, future studies about groundwater drought are essential for the sustainable use of groundwater during drought in Ethiopia.

Estimation of reliable groundwater recharge plays a significant role in groundwater resources management. Precipitation is the main source of groundwater recharge in Ethiopia, particularly in the Central Rift Valley catchment. Rainfall is, however, variable in space and time throughout the country, and as a result, groundwater recharge is also variable. In the northcentral and southwestern plateau of the country, where rainfall is high, higher groundwater recharge occurs than in the rest (Tamiru 2006). Chernet (1993) estimated the mean annual groundwater recharge varies between 0 and $400 \mathrm{~mm} /$ year for the major river basins by assuming that the annual baseflow separated from the total runoff is equal to the groundwater recharge in the catchment at which the discharge gauge station is found. Like rainfall, groundwater recharge varies geographically in the country; the southwest and north-central plateau of the country have the highest groundwater recharge (Kebede 2013). Moreover, the mean annual weighted groundwater recharge over the country is estimated at $39 \mathrm{~mm} /$ year using baseflow separation methods for individual basins and global remote sensing data (Döll and Fiedler 2008). Other studies in semiarid climate regions of Ethiopia such as Gebremeskel and Kebede (2017), Kahsay et al. (2019), Teklebirhan et al. (2012), Gebreyohannes et al. (2013), and Tilahun and Merkel (2009), used the WetSpass model for groundwater recharge estimation incorporating a spatial-temporal variation of hydrometeorology, land use/land cover, and soil texture variables.

In Ethiopia's Central Rift Valley catchment, meteorological drought frequency, and intensity have increased in the past decades (Seboka Tura 2017). This drought might propagate from meteorological to groundwater drought affecting groundwater recharge, groundwater levels, and groundwater discharge. Additionally, according to Thomas et al. (2019), groundwater demand increases in the region during drought periods. This may worsen groundwater drought intensity and frequency.

Drought propagation in the hydrological cycle can be assessed by comparing drought events of different drought types (Van Lanen 2006; Van Loon and Van Lanen 2012; Van Loon 2013; Tallaksen et al. 2006; Wossenyeleh et al. 2021). Groundwater recharge drought events can be investigated using threshold value methods and standardized groundwater index (SGI; Yevjevich 1967; Peters 2003;
Bloomfield and Marchant 2013). However, groundwater recharge is variable in space and time; therefore, spatially distributed numerical water balance models are used to simulate groundwater recharge. In this study, the WetSpass model (Abdollahi et al. 2017; Batelaan and De Smedt 2007) was used to simulate groundwater recharge with high temporal and spatial resolution. On the other hand, rainfall and evapotranspiration are used to investigate meteorological drought severity in space and time. Various studies have used SPEI and SPI drought indexes in Ethiopia's Rift Valley to investigate meteorological drought severity distribution in the region (Bekele et al. 2019; Moloro 2018; Nasir et al. 2021). In this study, SPI and SGI are used to investigate the drought propagation in the hydrological cycle and drought distribution.

This report aims to investigate drought propagation in the hydrological cycle of semiarid climate regions by applying a method for simulating meteorological drought and groundwater drought on recharge. The method developed in the Wossenyeleh et al. (2021) study that combines a water balance modeling, a variable threshold method to determine groundwater drought, and drought indices for meteorological drought was used. Moreover, drought propagation from meteorological to groundwater drought was also investigated.

\section{Study area and data}

The study area consists of the Bilate River catchment in Ethiopia's Central Rift Valley basin and has a surface area of $5,419 \mathrm{~km}^{2}$ (Fig. 1). The main perennial river in the catchment, Bilate River, flows from the north to south and outflows to Lake Abaya. The catchment is characterized by the rift, transitional escarpment, highlands, and wide valleys with small and large streams and narrow flatlands between valleys caused by the following processes: volcano-tectonic, rifting, erosion, deposition, and land-use practices (Ayenew et al. 2008). The land surface elevation ranges from $3,331 \mathrm{~m}$ above sea level (asl) in the north to $1,174 \mathrm{~m}$ asl at the most southerly part of the catchment; moreover, based on the Thornthwaite climate classification, the catchment is classified as a semiarid climate zone (Walker 2003).

\section{Meteorological data}

Thirty-four years (1980-2013) of meteorological data were collected from the Ethiopian Meteorological Agency (EMA) from 11 meteorological stations shown in Fig. 1. The stations are reasonably distributed within and around the catchment area at different elevations recording daily rainfall, temperature (maximum, minimum), wind speed, and other climatic data. Missing data were filled using linear interpolation and ordinary least squares (OLS) methods. Potential 


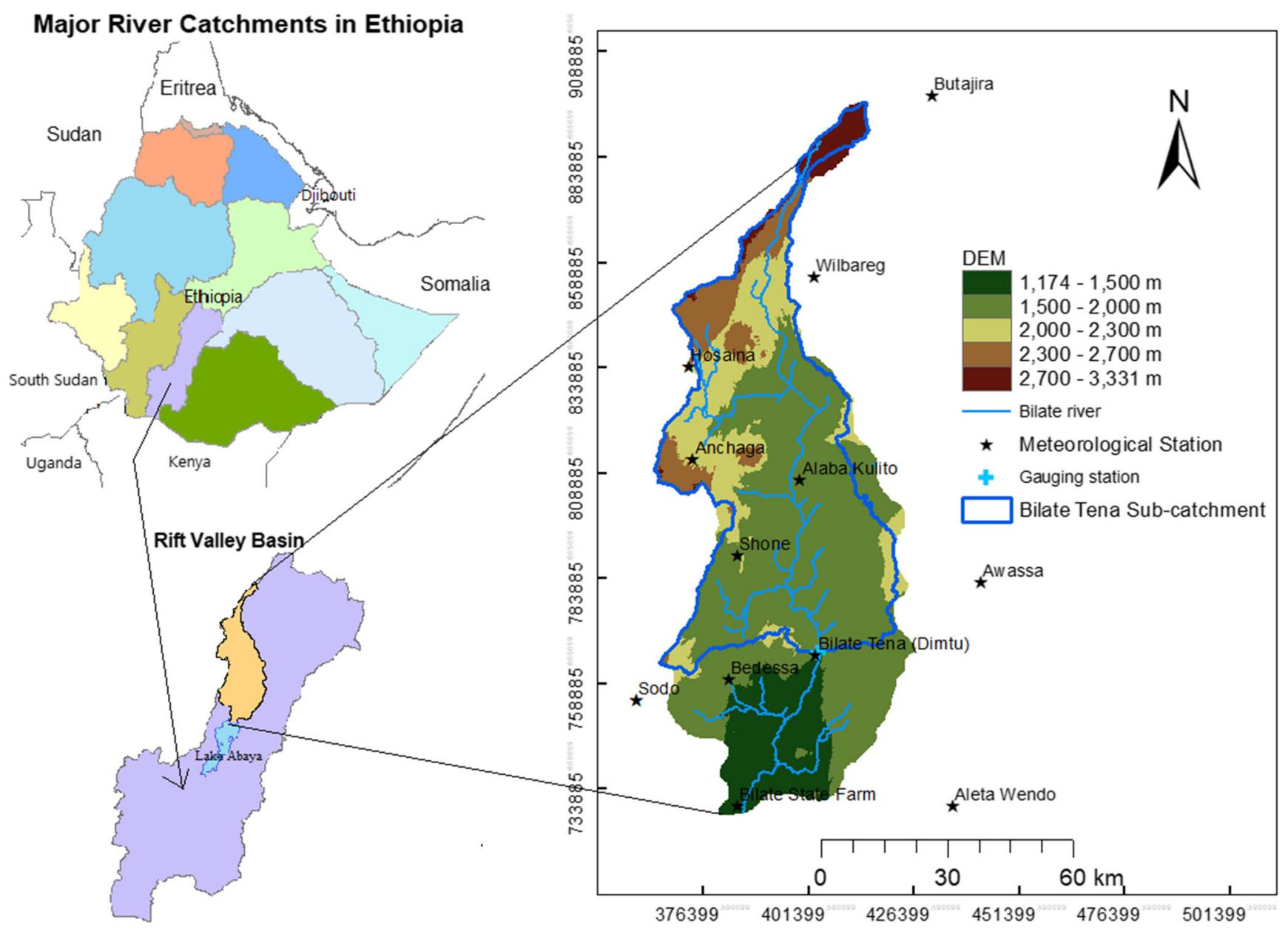

Fig. 1 Location and digital elevation model (DEM) of the study area

evapotranspiration (PET) was calculated using the FAO Penman-Monteith equation from observed meteorological data.

Figure 2 shows the seasonal variation of rainfall. The summer periods, which are June, July, August, and September, are considered rainy months in the catchment. The yearly mean of rainfall between 1980 and 2013 varies from 900 to $1,500 \mathrm{~mm}$. Moreover, the monthly average temperature recorded during the analysis period is $18{ }^{\circ} \mathrm{C}$. The spatial average yearly total potential evapotranspiration ranges from 876 to $2,550 \mathrm{~mm}$ in the study area.

Figure 3 shows the spatial distribution of the monthly total rainfall in the catchment interpolated using Bayesian kriging of total rainfall at the 11 meteorological stations. Rainfall is high in the north and north-west highlands of the catchment, while rainfall is much lower in the catchment's lowland areas.

\section{Soil and land use/land cover}

Soils in the catchment are classified into four types based on the FAO (1998) and USDA soil texture classification (Fig. 4a). Silty loam and loam dominate the catchment, and soil depths vary between 1.00 and $2.00 \mathrm{~m}$ (FAO 1998).

Since the study area is mainly dominated by governmentowned agricultural land and small-scale farms, the land use/ land cover map is developed based on the digitized map of

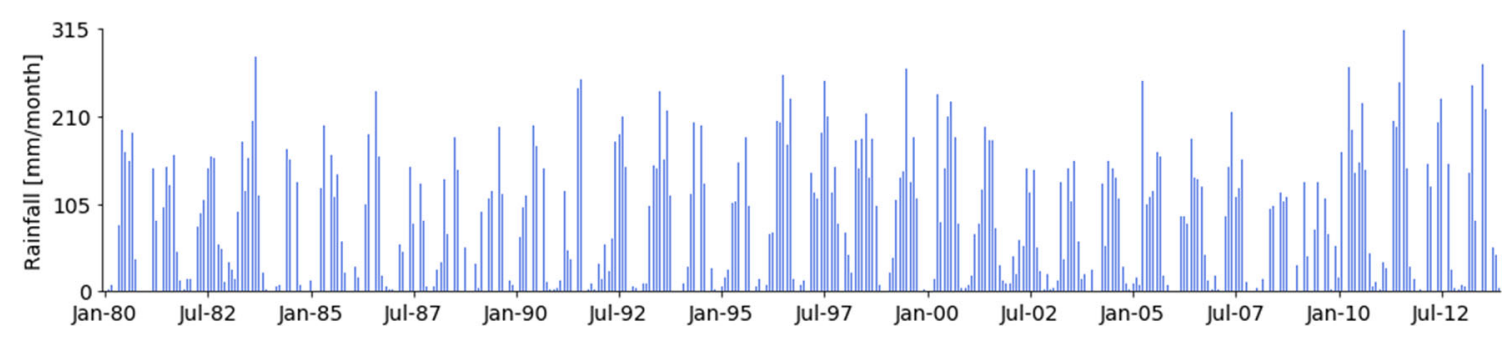

Fig. 2 Average monthly total rainfall distribution of Bilate catchment using 11 meteorological stations 
Fig. 3 Spatial average monthly total rainfall distribution of Bilate catchment using 11

meteorological stations

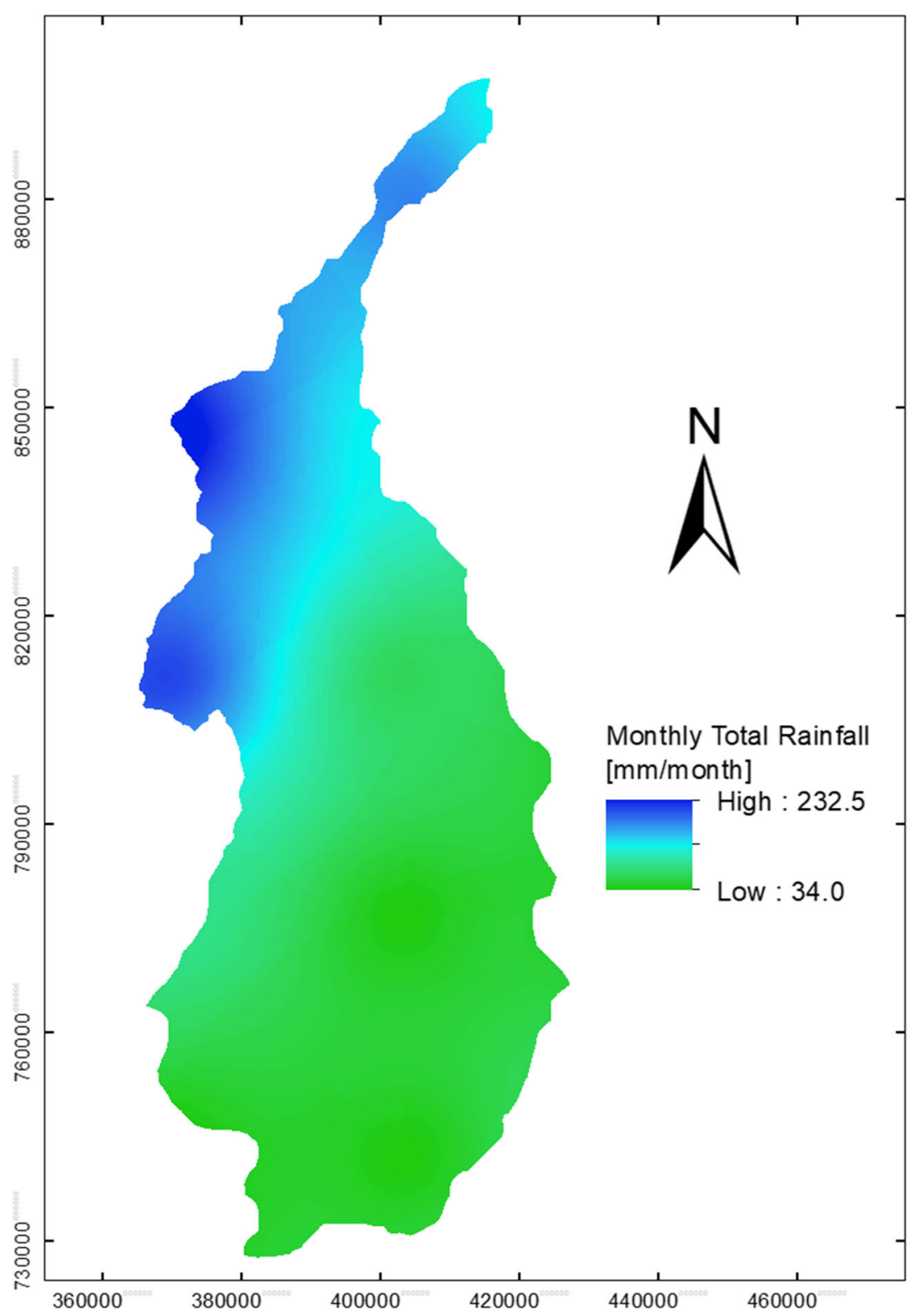

1978 made by the Ethiopian Ministry of Agriculture. The digitized map describes the land use as "state farm", "crop cultivation', 'moderately cultivated', 'dense woodland/perennial', 'bare land', 'grassland', 'shrubland', 'woodland/forest', and 'waterbody'. However, in this research, the map was modified based on the land use/land cover classification set up by the WetSpass model input guide (Fig. 4b). Because of state farms and population density in the surrounding cities and towns, most of the catchment is cultivated (Tesfaye Tessema 2010).

\section{Slope}

A spatially distributed slope map is derived from the digital elevation model that covers the area (Fig. 5). In the catchment, steep slopes are found around the mountainous part of the western edge, and gentle slopes are dominant in the cultivated land of the eastern edge. The slope and elevation variation in the catchment leads to significant erosion and deposition processes (Förch and Althoff 2009).

\section{Hydrogeology}

According to the FAO (1998) geological map, OligoceneMiocene volcanic rock is dominant in the catchment (Förch and Althoff 2009). Geological features as such faults, fractures, and graben and horst structures play a significant role in groundwater flow. This can be seen from the many springs that discharge groundwater onto the land surface along faults and fracture zones beneath the catchment's mountainous 


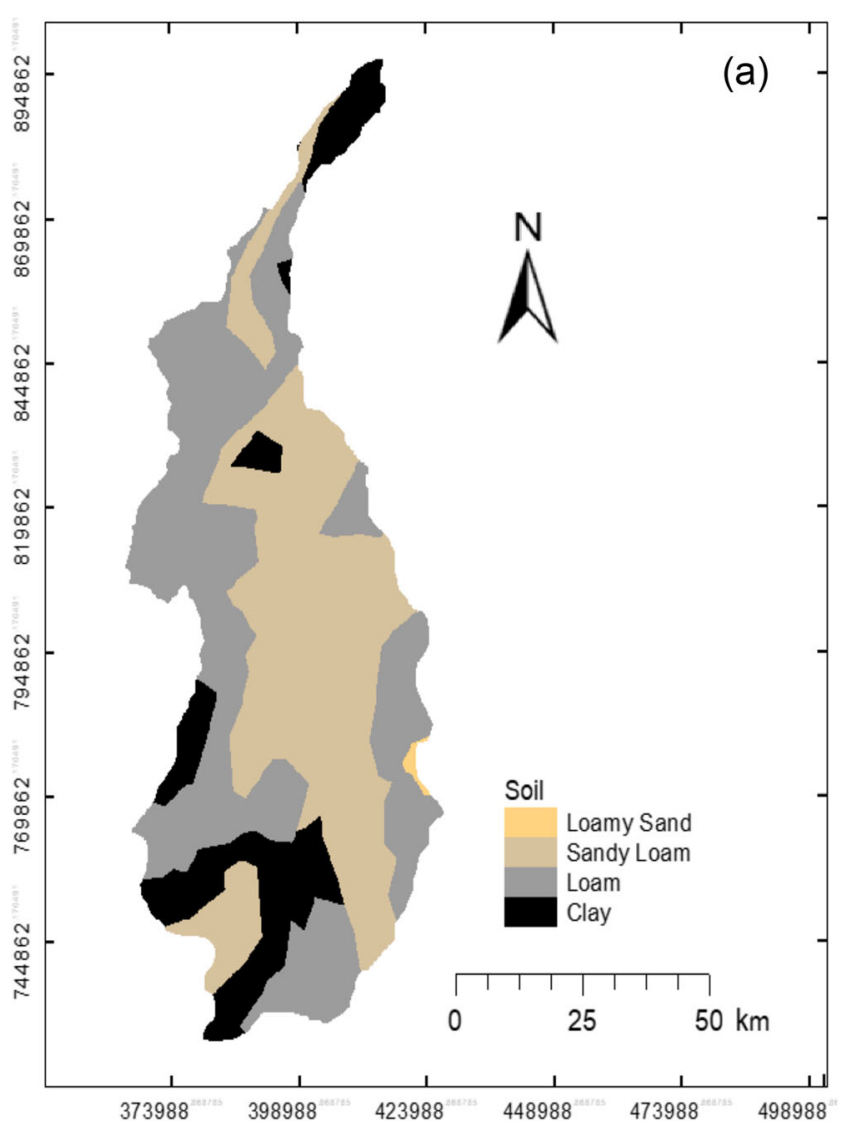

Fig. 4 a Soil texture distribution and $\mathbf{b}$ land use/land cover classification

region (Dereje and Nedaw 2019). These springs discharge shallow groundwater; however, groundwater abstraction wells in the catchment extract water from the deep aquifer (Tesfaye Tessema 2010).

The average groundwater depth is $35 \mathrm{~m}$, measured from 51 boreholes in the catchment by the water resources bureau of the Southern Nations, Nationalities and People's Region. Moreover, the observation data indicate that groundwater depth in most of the study area is deeper than $5 \mathrm{~m}$. As a result, groundwater depth does not influence the water balance calculation of the WetSpass model as no evapotranspiration from groundwater happens in areas with such deep water tables.

\section{Methodology}

The study was divided into three parts: groundwater recharge estimation, meteorological drought analysis, and groundwater drought analysis (Fig. 6). First, drought severity with respect to rainfall was investigated using meteorological drought analysis. Then, a water balance model was built to estimate temporally and spatially distributed groundwater recharge. Groundwater drought analysis was performed on the calculated time series of groundwater recharge. Finally, drought propagation in the hydrological cycle was investigated by

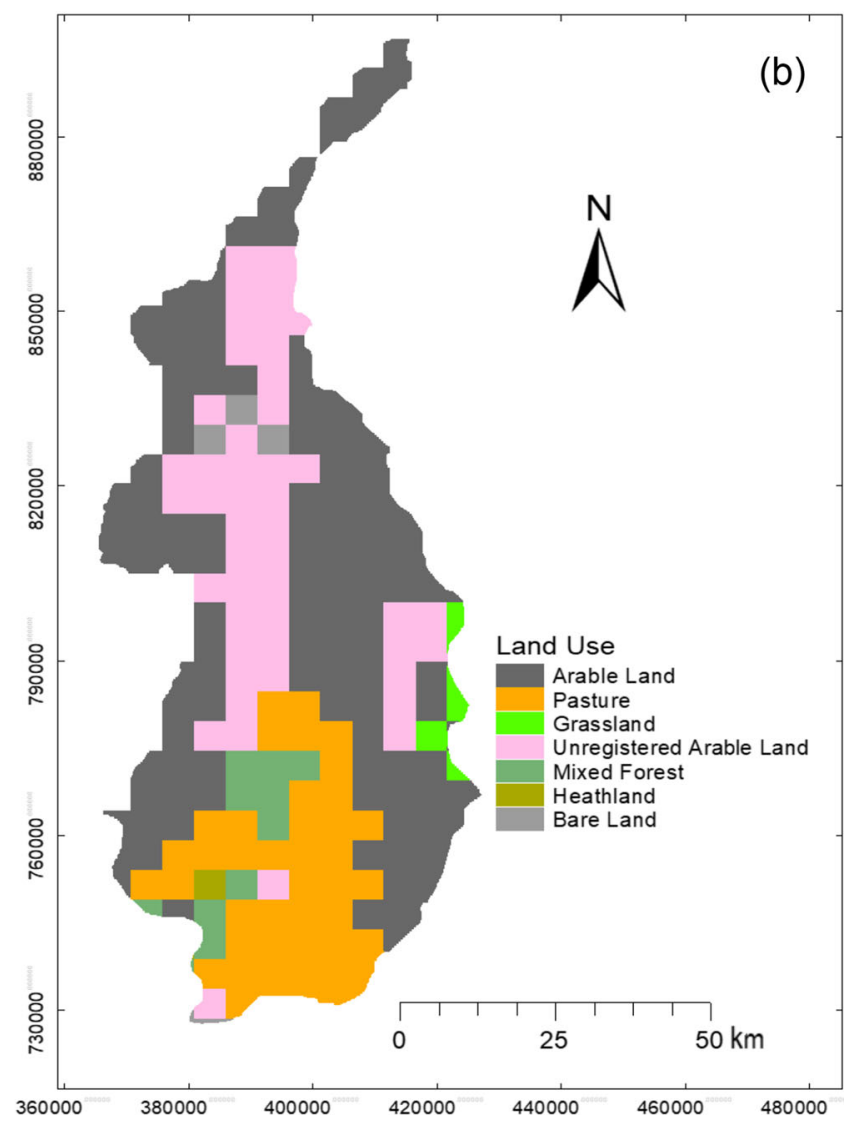

comparing groundwater recharge drought occurrence, intensity and frequency to meteorological drought.

\section{Meteorological drought analysis}

The standardized precipitation index (SPI) is used to determine the spatial and temporal extent of meteorological drought severity (McKee et al. 1993). Thirty-four years of monthly average rainfall (see section 'Meteorological data') for the period 1980-2013 were used to calculate SPI and identify meteorological drought events and severity.

A long-term rainfall probability distribution was used to calculate SPI on different time scales (McKee et al. 1993). The probability distribution was used to fit the long-term rainfall, and then the fitted distribution is transformed to a normal distribution using the gamma distribution (Thom 1958). That results in the mean SPI value being zero for the given location and analysis period (Edward and McKee 1997). The SPI value indicates rainfall deviation from the median rainfall; a positive value means greater than the median, and negative values indicate less than the median; hence, an extreme drought event occurs when the index reaches the value of -2.0 or less (Table 1). The drought event ends once the SPI becomes positive, indicating a higher rainfall intensity than the long-term average value. According to McKee et al. (1993), drought 
Fig. 5 Slope distribution of the Bilate River catchment

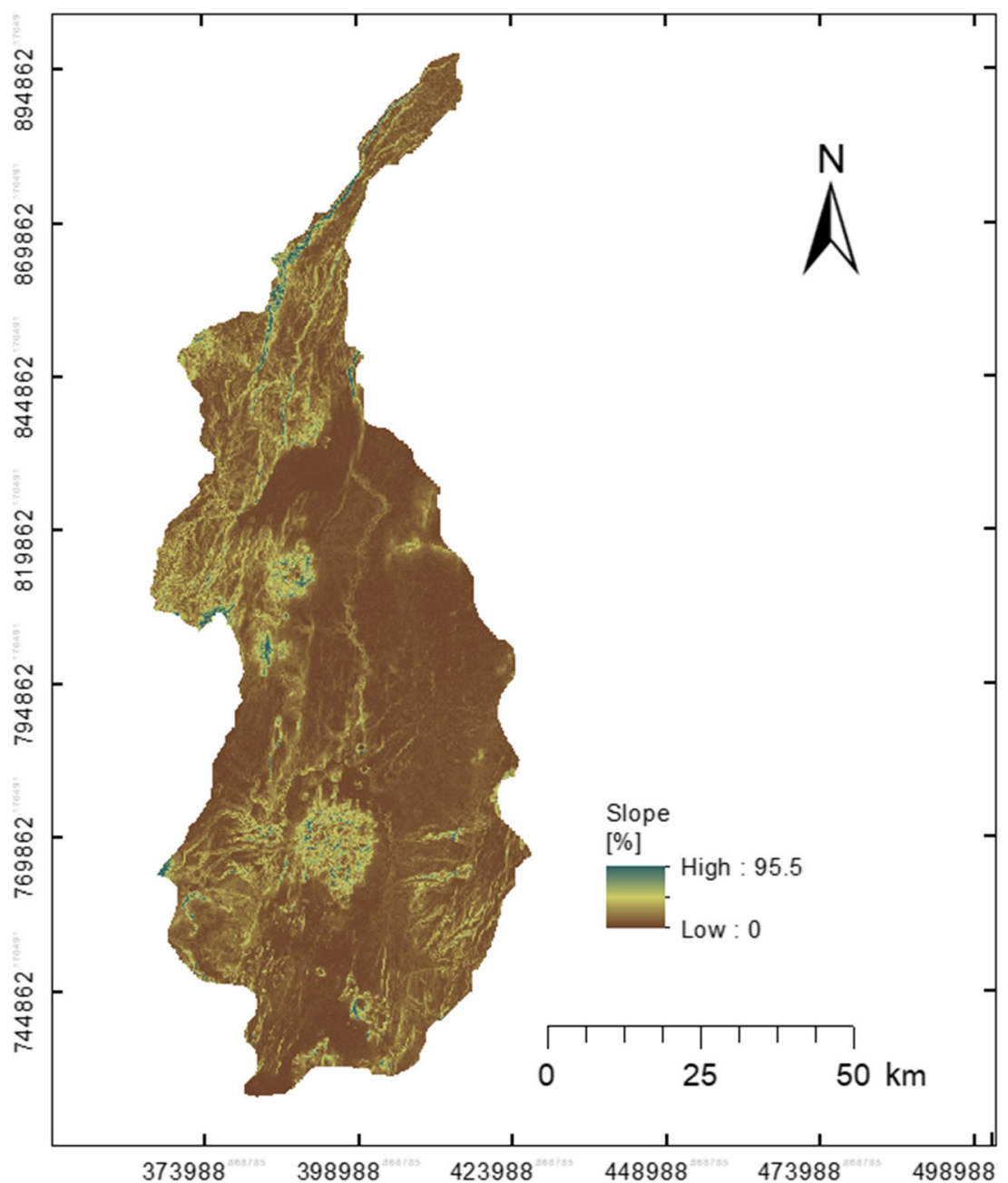

severity categories can be defined based on the SPI value as shown in Table 1.

In this study, monthly SPI-4 (quarterly), SPI-6 (sixmonthly) and SPI-12 (annual) values were used to investigate the long-term meteorological drought severity distribution on a temporal and spatial scale. Moreover, this SPI was used to investigate meteorological drought propagation to groundwater.

\section{Groundwater drought estimation}

Physical and meteorological factors govern the estimation of groundwater recharge in a catchment. It is estimated at a monthly timestep using a physically based distributed water balance model called WetSpass (Batelaan and DeSmedt 2001, 2007). The model was adjusted to enabling water balance calculation at a monthly timestep instead of a seasonal timestep (Abdollahi et al. 2017). In contrast to the seasonal approach (summer/winter season), the monthly approach enables consideration of the specific conditions of a study area (e.g., more than two seasons) and, thus, has broader applicability.

\section{Model inputs}

The model inputs are spatially distributed maps for land use/ land cover, soil, slope, groundwater depth, and four meteorological parameters: rainfall, potential evapotranspiration, temperature, and wind speed (see section 'Meteorological data'). The meteorological input parameters were interpolated for the catchment scale using Gaussian kriging. All spatially distributed input maps were prepared in 180-m resolution using a Python-based geographical information system (GIS) tool, resulting in monthly time-series groundwater recharge maps at the same spatial resolution.

The default land use/land cover parameters of the WetSpass model are based on typical land uses and land covers for a humid climate as the software was initially developed for applications in Belgium. For Ethiopia's semiarid climate, particularly for the Bilate River catchment, some adjustments of the parameters' values are introduced based on 
Fig. 6 Conceptual framework of the study

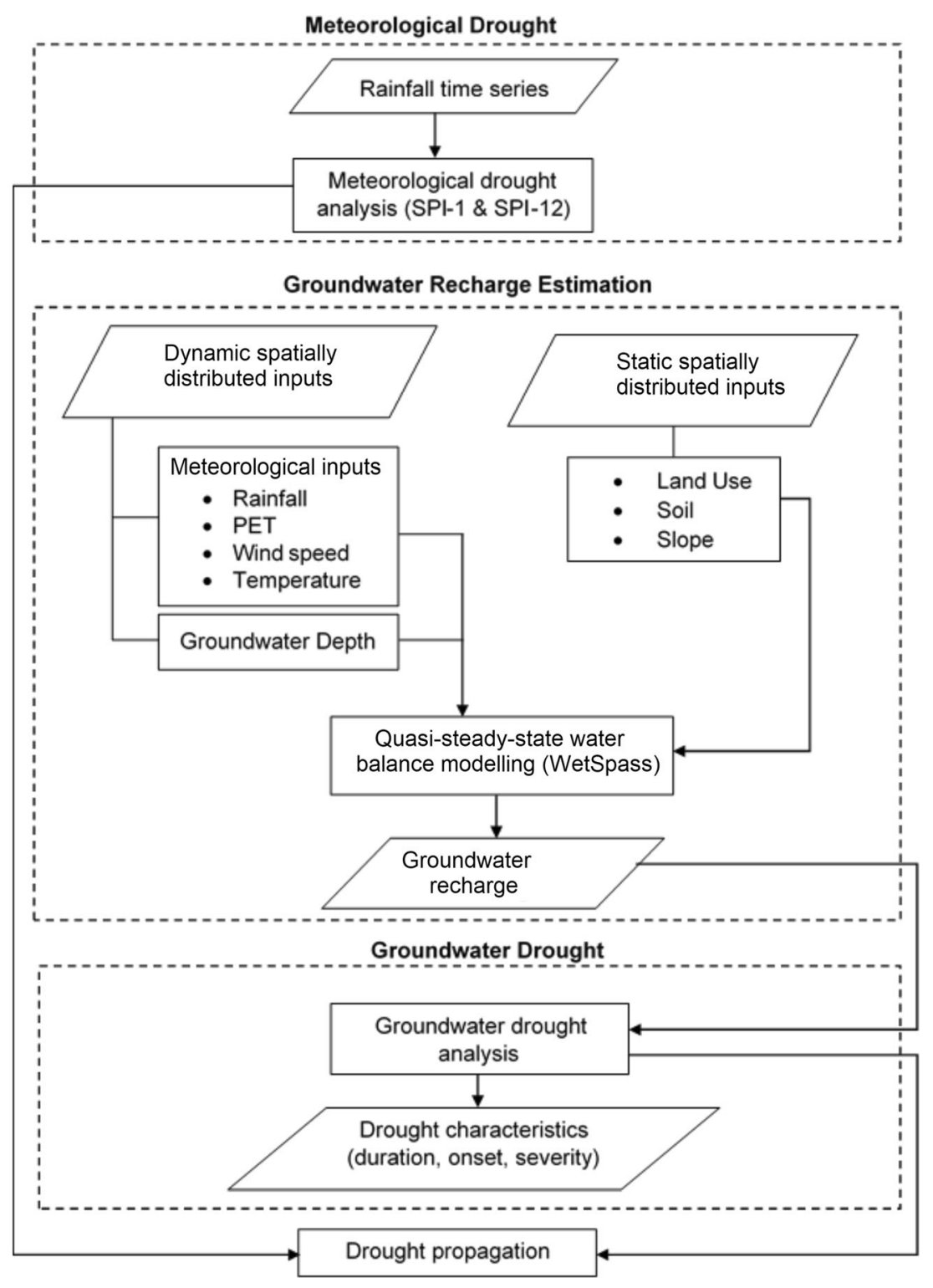

Gebreyohannes et al. (2013). The adjustments are made based on the nature of the vegetation, bare-land, and imperviousness of the catchment. Accordingly, for this study, the following adjustments to the default values are made: (1) $30 \%$ decrease in the value of the leaf area index, (2) 10-30\% root-depth decrement based on the land use types and (3) $20 \%$ increase of the area of bareness of all land use classes.

Table 1 Drought severity categories based on SPI values (McKee et al. 1993)

\begin{tabular}{ll}
\hline SPI values & Drought category \\
\hline 0.0 and more & No \\
0.0 to -0.99 & Mild \\
-1.0 to -1.49 & Moderate \\
-1.5 to -1.99 & Severe \\
-2.00 and less & Extreme \\
\hline
\end{tabular}

\section{Calibration}

Four global parameters - evapotranspiration parameter $(\alpha)$, surface runoff parameter (LP), interception parameter $(a)$, and average intensity - and three local parameters (slope factor, land factor, and soil factor) of the WetSpass model were calibrated. The model was manually optimized according to the goodness of fit between the simulated base-flow from simulated groundwater recharge of Bilate-Tena subcatchment (Fig. 1) and the separated base-flow from observed river discharge using WETSPRO (Willems 2009) at Bilate-Tena gauging station (Fig. 1) for the years between 1981 and 1985.

Monthly base-flow is calculated from the previous month's storage and groundwater recharge $\left(R_{\mathrm{m}}\right)$ in the considered month (Abdollahi et al. 2017). This is expressed as follows:

$Q_{\mathrm{b}(t)}=\beta Q_{\mathrm{b}(t-1)}+0.001 N_{\mathrm{m}}(1-\beta) \varnothing R_{\mathrm{m}}$ 
where $\beta$ is a storage parameter [-] between 0 and $1, Q_{\mathrm{b}}(t-1)$ is the base-flow from the previous month [ $\mathrm{m}^{3} /$ month], $N_{\mathrm{m}}$ is the number of days per month ( $\approx 30$ days $)$, and $\varnothing\left[\mathrm{m}^{2} /\right.$ day] is the recharge contribution to current baseflow. For the pixel area $A$ $\left[\mathrm{m}^{2}\right]$ with recession index $k$ [day], it would be:

$\varnothing=\frac{1.15 A}{k}$

The result of the calibration should be evaluated both qualitatively and quantitatively. The Nash Sutcliffe efficiency coefficient (NSE) and the coefficient of determination $\left(r^{2}\right)$ are used to express the model's overall efficiency.

\section{Groundwater drought analysis and drought propagation}

A groundwater recharge drought analysis was performed on the 34-year (1980-2013) simulated groundwater recharge time-series. A threshold level method with a variable threshold value was used to determine groundwater recharge drought (Van Loon and Van Lanen 2012; Vidal et al. 2010; Yevjevich 1967).

In order to do that, first, a separate frequency analysis was conducted for each of the 12 months. For most drought studies, the threshold level is within the 70-95th percentile range of the probability of exceedance (Van Loon 2013). Therefore, each month's threshold level value was determined as the 80th percentile of the probability of exceedance of monthly groundwater recharge in that month in the 34-year series (1980-2013). For each month of the year, the groundwater recharge values in the time series were ranked from highest to lowest, and then the 80th percentile of groundwater recharge was calculated for each month. Groundwater recharge drought was characterized in terms of the number of droughts, duration of droughts, and drought severity (cumulative volume deficit from the threshold level; Peters 2003).

Moreover, a standardized groundwater drought index (SGI) and standardized precipitation index (SPI) were used to analyze drought propagation in the hydrological cycle, which is from the meteorological drought to groundwater drought. The standardized groundwater drought index (SGI) was introduced by Bloomfield and Marchant (2013) to analyze drought on groundwater level. In this research, SGI was calculated from groundwater recharge by applying appropriate normalization procedures. The long-term delayed groundwater recharge time-series was normalized by fitting to a gamma distribution. Then, as for SPI, the standardized groundwater drought index (SGI) was calculated for the spatial monthly averaged groundwater recharge time-series between 1981 and 2013. The results of the groundwater recharge drought analysis were combined with monthly SPI values to gain insight into the propagation of drought in the hydrological cycle and to assess the groundwater system's response to drought.

\section{Results and discussion}

\section{Model calibration}

An initial flow value of $0.75 \mathrm{~m}^{3} / \mathrm{s}$, one filter step, a recession constant of 65 days and a subflow filter (wf) parameter of 0.6 was set for base-flow separation on WETSPRO. Since the catchment had a thick unsaturated zone, manual calibration is used to match the simulated and filtered base-flow and filtered base-flow; a 3-month groundwater recharge delay gave a better match. This 3-month delay of groundwater recharge could be related to the nature of the hydrogeology of the catchment or the amount of deep infiltration; however, more detailed modeling or study of the unsaturated soil is needed to estimate the delay time, as done in a temperateclimate case study reported by Wossenyeleh et al. (2020). An optimized $\beta$ value of 0.2 and recharge contribution parameter of $0.0066 \mathrm{~m}^{2} / \mathrm{s}$ is obtained using Eq. (2). The simulated baseflow from the WetSpass recharge and monthly filtered base-flow separated from river discharge using WETSPRO gives a good calibration result with a Nash-Sutcliffe efficiency coefficient of 0.69 and coefficient of determination of 0.86 (Fig. 7).

\section{Meteorological drought}

Figure 8 shows the meteorological drought occurrence and severity between 1980 and 2013 using 11 meteorological stations in the Bilate River catchment. The meteorological drought calculations are based on monthly SPI (SPI-1) shown in Fig. 8a and annual SPI (SPI-12) shown in Fig. 8b. The results show that the severity and frequency of drought depend on the calculation period of SPI. The drought severity category varies from extreme to no drought based on SPI-1 and severe to no drought based on SPI-12. The SPI-12 values show less severe drought categories.

Between 1980 and 2013, one extreme and eight severe meteorological droughts at a monthly scale are identified using SPI-1. Using average SPI-12 calculated from each month of SPI-12, only one severe meteorological drought (in 2003-2004) is identified. This shows that short meteorological droughts are frequent while longer meteorological droughts occur with lower frequency.

Meteorological drought severity is also variable on a spatial scale - for example, Fig. 9 shows that in the hydrological year of 2008-2009, the drought severity categories vary from no drought to severe in the study area. Moreover, the spatial distribution of the drought severity category is also different for different SPI calculation periods (Fig. 9a-c). 


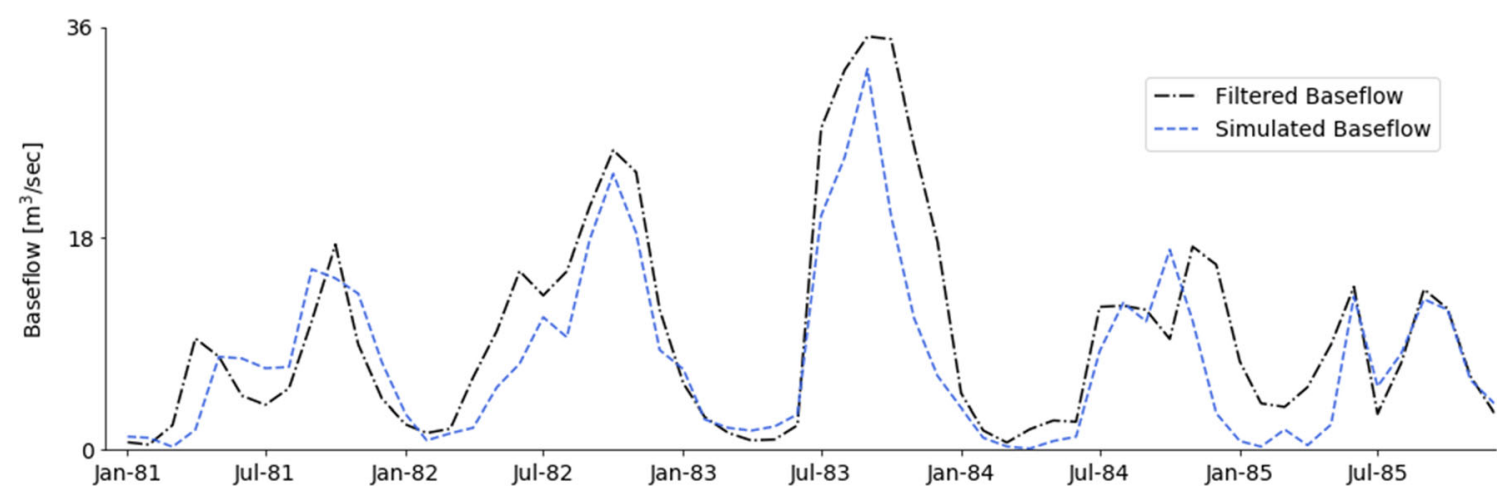

Fig. 7 Simulated baseflow based on WetSpass output: groundwater recharge vs. monthly filtered baseflow from flow measurements at the Bilate-Tena gauging station

\section{Groundwater recharge}

Figure 10 shows the temporal variation of estimated groundwater recharge and total monthly rainfall. The estimated groundwater recharge clearly shows the seasonal dynamics. That means that in the rainy months (July-Oct) calculated recharge is high; while in the dry months (Nov-Feb) a low recharge was estimated. The estimated recharge in most of the study area is within the 75 percentile range of the distribution; only a few outliers are recorded in some months (Fig. 11).

The spatial distribution of groundwater recharge (Fig. 12) shows that the calculated groundwater recharge ranges from 0 to $37 \mathrm{~mm} / \mathrm{month}$ with a spatial average of $10.10 \mathrm{~mm} / \mathrm{month}$.
This result is $9.8 \%$ of the monthly average rainfall of the study area and this estimated groundwater recharge confirms the findings of Dereje and Nedaw (2019) for upper Bilate catchment, showing that the average groundwater recharge is $9.4 \%$ of the annual precipitation. The influence of rainfall distribution in the catchment is significantly noticeable in the spatial distribution of groundwater recharge. The north and northwest highlands of the catchment have high groundwater recharge, where rainfall is highest (see Fig. 3).

Groundwater recharge is also highly correlated with land use type (Table 2). High groundwater recharge is estimated in bare land and arable land; this might be because of the dominance of sandy loam and loamy soil types and the gentle
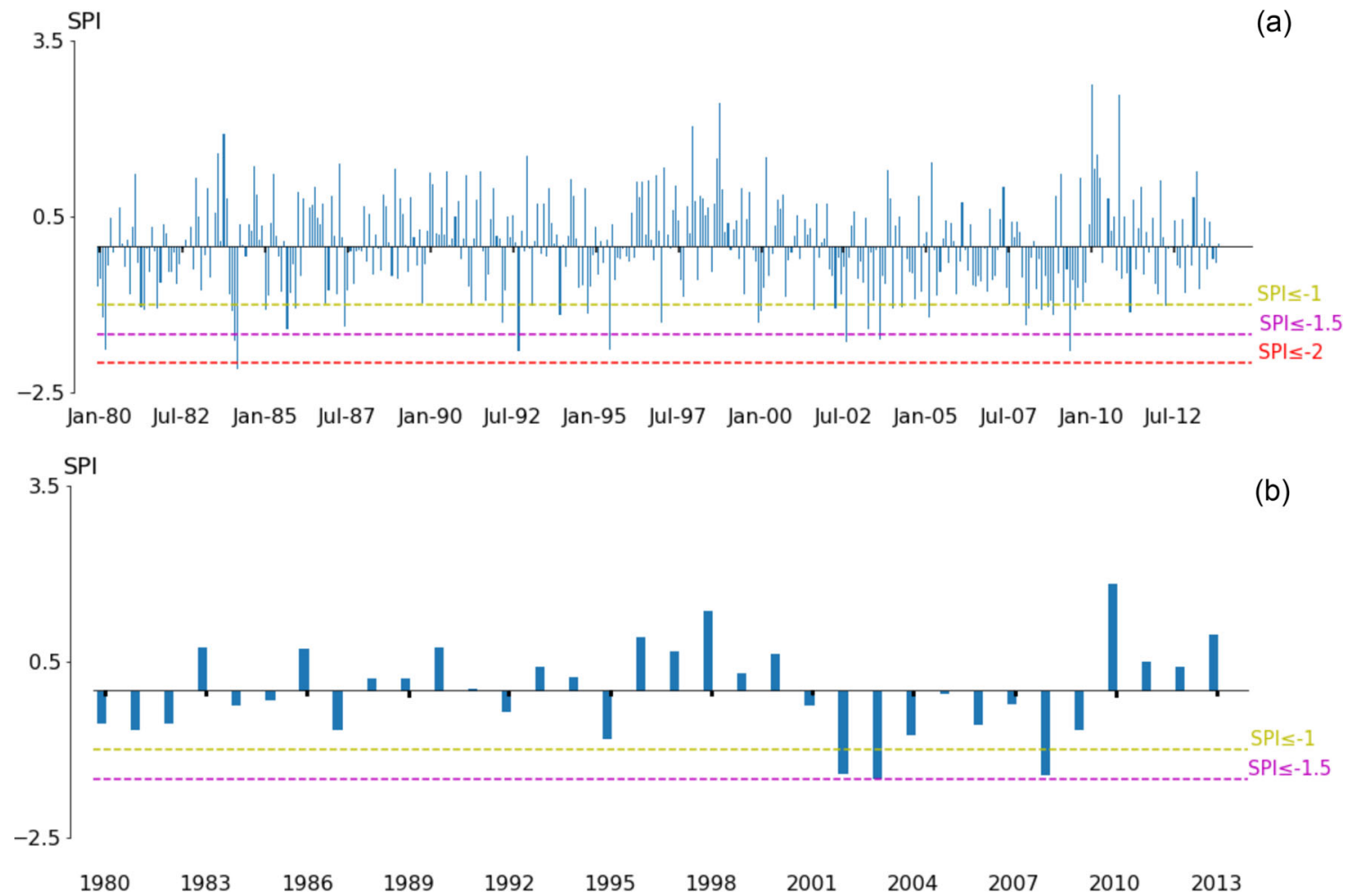

Fig. 8 Meteorological drought occurrence and severity based on $\mathbf{a}$ Monthly SPI value and $\mathbf{b}$ average SPI-12 value calculated from each month of SPI-12 for $1980-2013$ 

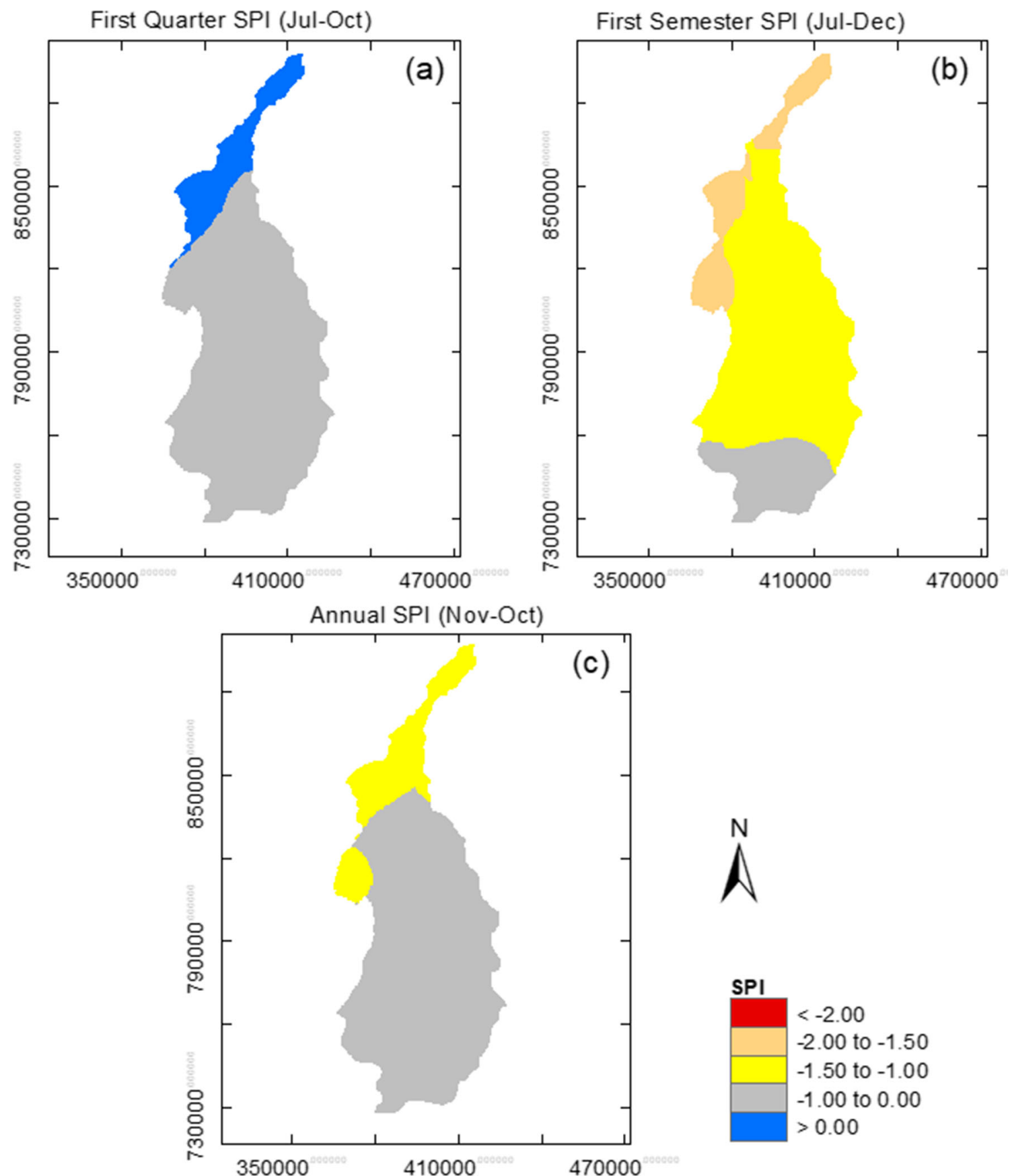

Fig. 9 Spatially distributed meteorological drought severity based on the a SPI-4 (quarterly) value, b SPI-6 (six-monthly) value, and c SPI-12 (annual) value for the hydrological year of 2008-2009

slope in those particular areas. In the forest and pasture areas in the southwest of the catchment, groundwater recharge is relatively low.

\section{Groundwater drought}

Figure 13 shows the groundwater recharge drought events between 1980 and 2013 calculated using a variable threshold method. Negative anomalies of groundwater recharge from the threshold indicated drought events. Fourteen drought events with a cumulative recharge deficit higher than $5 \mathrm{~mm}$ were observed during the analysis. The drought event duration varies from 1 to 22 months. The drought events with the longest duration were from December 2001 to September 2003 and from December 2003 to September 2005, which lasted for 22 months, whereas the drought event from February 2007 to August 2008 lasted for 19 months. Droughts with shorter durations were observed in December 

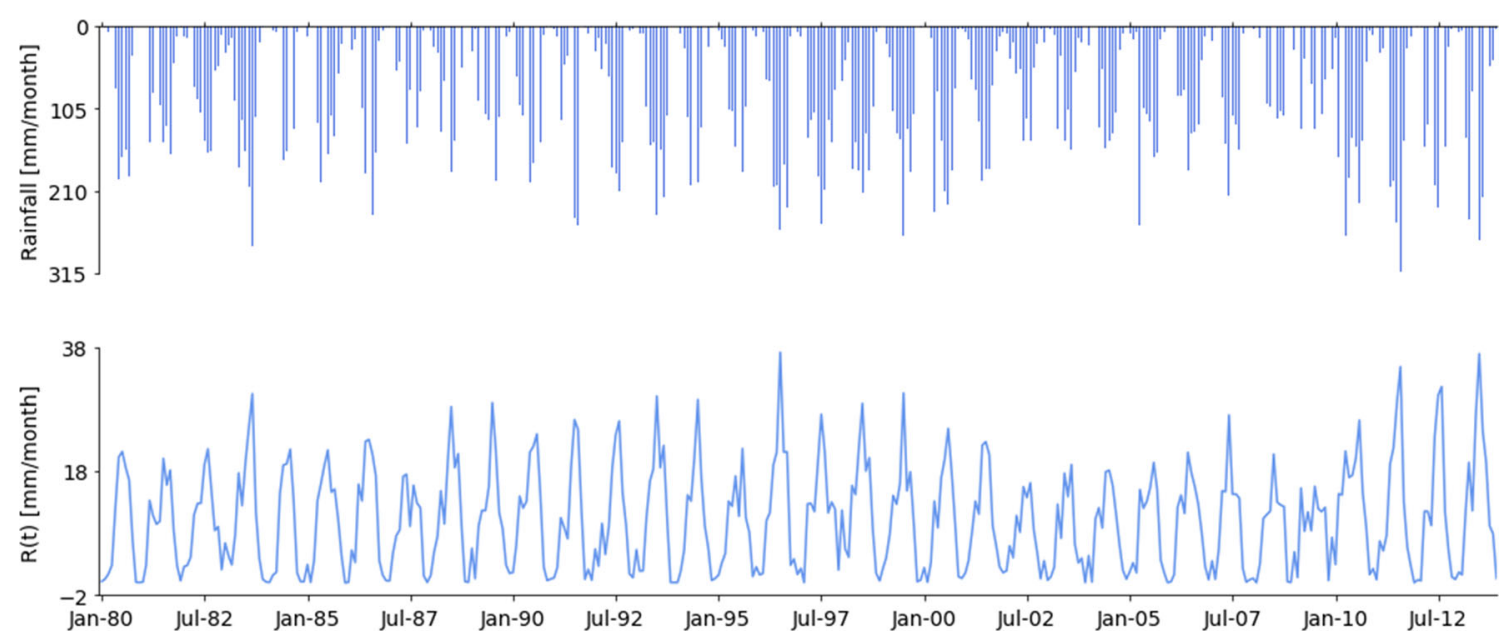

Fig. 10 Average monthly groundwater recharge distribution and average monthly total rainfall

1985, April 1989, January 1997, April 1997, January 1999, November 2010, September 2011, and September 2012 (1 month). The drought from December 2001 to September 2003 with a cumulative deficit recharge of $60.74 \mathrm{~mm}$ was the most severe within the analysis period. The drought event from February 2007 to August 2008 resulted in a cumulative deficit recharge of $36.94 \mathrm{~mm}$. Both severe drought events have a drought volume several times larger than the average estimated recharge of $10.10 \mathrm{~mm} /$ month.

Table 3 shows some of the groundwater drought characteristics between 1980 and 2013 for the major groundwater recharge events calculated using the variable threshold method as shown in Fig. 13. The average duration of groundwater drought in the period between 1980 and 2013 was 6 months. However, most of the droughts occurred between 2001 to 2009, including several severe drought events.

\section{Drought propagation in the hydrological cycle}

The propagation of drought in the hydrological cycle from meteorological drought to groundwater recharge was analyzed using SPI-1 and monthly groundwater recharge SGI. Since not all negative SGI are considered as groundwater drought, during drought propagation analysis, only more severe groundwater recharge droughts, which are the lowest $20 \%$ SGI, are considered. Table 4 indicates the lag time and the number of meteorological droughts (SPI-1) before the onset of groundwater recharge drought between 1980 and 2013. The lag time was calculated as the time between the start of the meteorological drought and the monthly groundwater recharge SGI. Meteorological drought was observed before every groundwater recharge drought with an average lag time of 1.7 months between the beginning of meteorological drought and the beginning of SGI groundwater recharge drought event.

Moreover, a number of different ranges of severity of meteorological drought (from moderate to severe) happened earlier than the onset of groundwater drought impacted the groundwater drought characteristic-for example, the groundwater droughts that occurred after November 1983, April 2001, February 2007 (Figs. 13 and 14). Further findings show that mild and moderate meteorological droughts also propagate to groundwater, e.g., minor groundwater droughts starting in November 1981, December 1987, September 1991, and November 2010.

Figure 14 gives insight into drought propagation in the hydrological cycle by comparing groundwater recharge

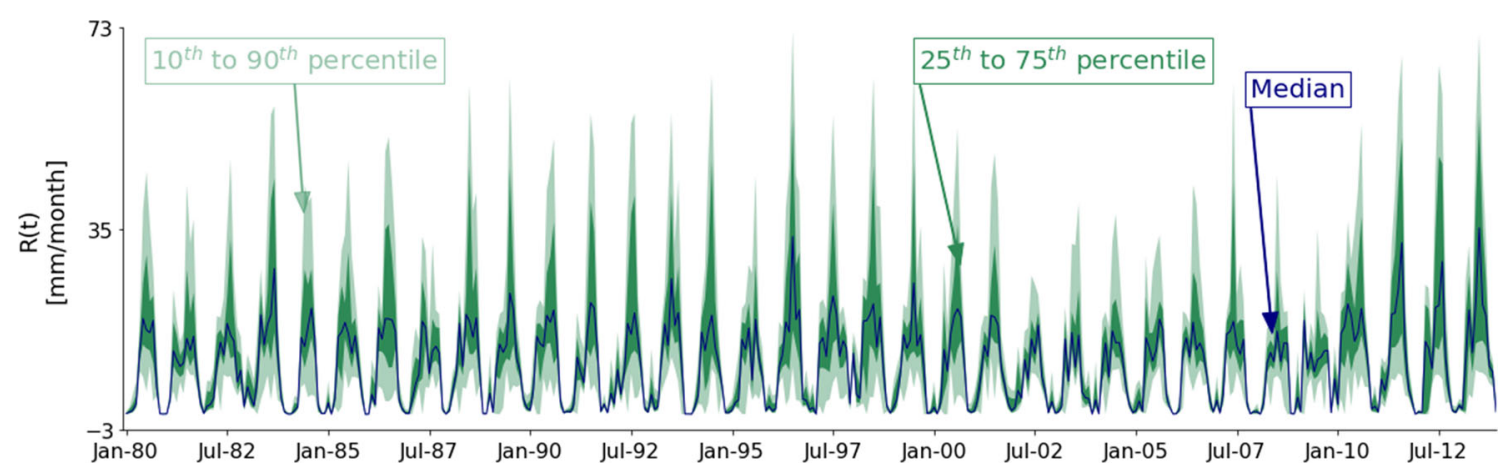

Fig. 11 Temporal variation of estimated groundwater recharge. The dark blue line is the 50th percentile curve (median) and shows the median groundwater recharge value for each month. The green shadow area

represents the interquartile range (IQR). Moreover, the light-greenshaded area represents the lowest and highest $10 \%$ of each month's groundwater recharge values 
Fig. 12 Spatial monthly averaged groundwater recharge distribution from 1980 to 2013 in the Bilate

River catchment, estimated using WetSpass
Table 2 Average monthly groundwater recharge based on the land use classes. $S D$ standard deviation

\begin{tabular}{lcc}
\hline Land-use type & \multicolumn{2}{c}{ Groundwater recharge $[\mathrm{mm} / \mathrm{month}]$} \\
\cline { 2 - 3 } & Mean & $\mathrm{SD}$ \\
\hline Arable land & 9.41 & 4.54 \\
Pasture & 6.99 & 1.48 \\
Grassland & 9.41 & 0.94 \\
Unregistered arable land & 10.44 & 4.25 \\
Mixed forest & 9.51 & 1.37 \\
Heathland & 6.27 & 1.34 \\
Bare land & 18.70 & 6.25 \\
\hline
\end{tabular}

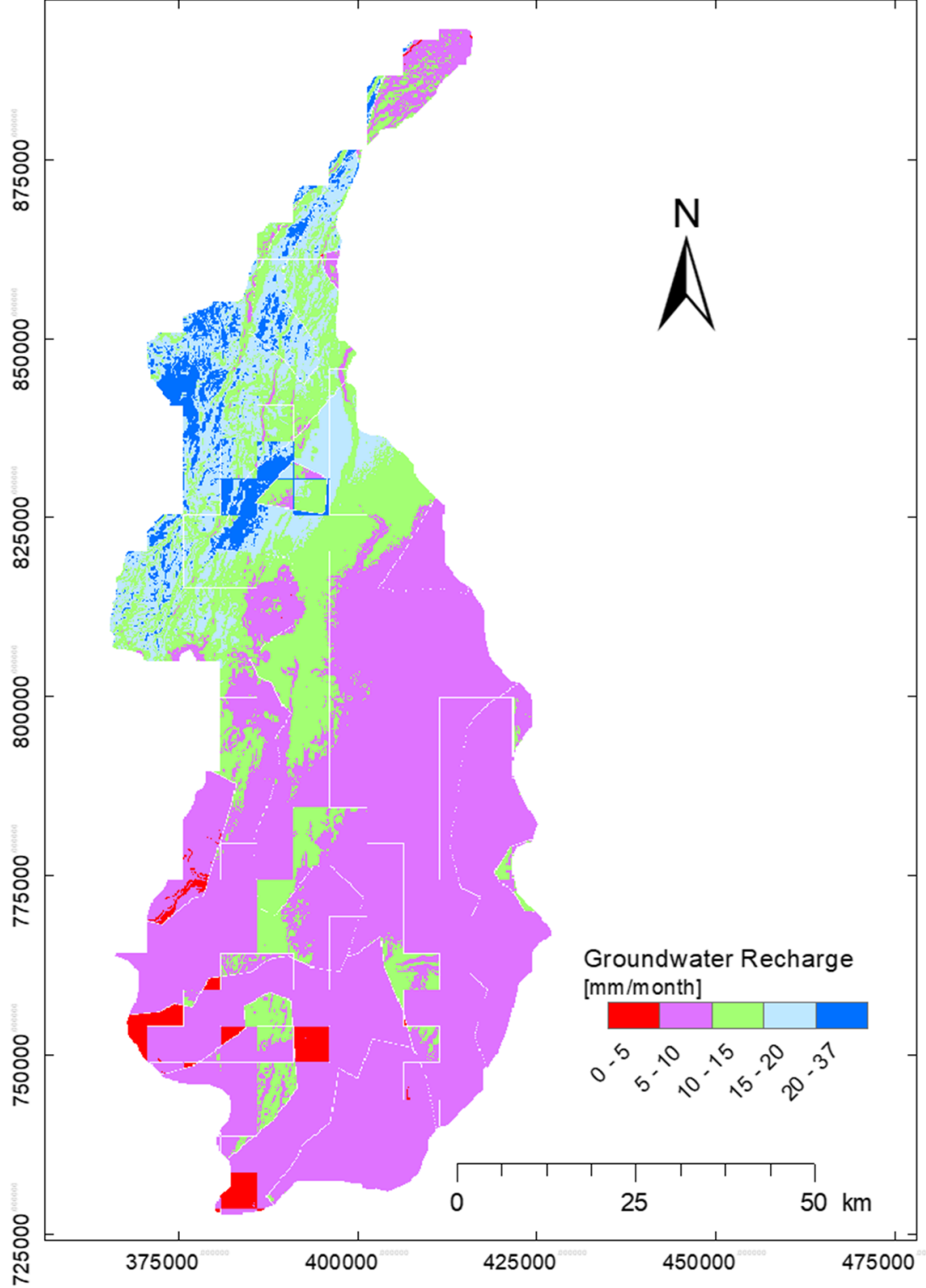

drought to meteorological drought. Frequent meteorological droughts were observed in Fig. 14 before every groundwater recharge drought.

\section{Discussion}

The study about temporal and spatial meteorological drought characterization in Ethiopia by Bisrat and Berhanu (2019) indicated that water scarcity occurred in the hydrological year of 2001-2002 and 2008-2009 because of meteorological drought. The result of this study also confirmed that more frequent meteorological droughts happened in these hydrological years. Additionally, most meteorological droughts are observed in the months of November, December and January.

Drought propagation in the hydrological cycle shows that the multiyear meteorological droughts of 1981-2013 


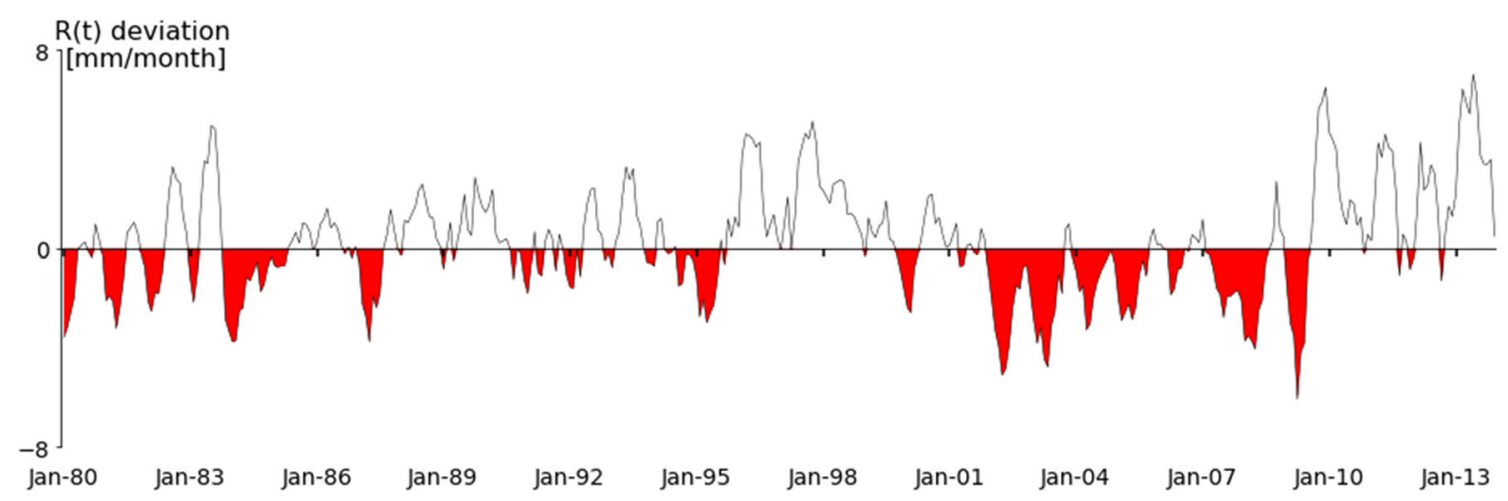

Fig. 13 Monthly groundwater recharge deviation from the threshold value. The red color indicates groundwater recharge drought events

Table 3 Groundwater recharge drought characteristics (onset, number of events, duration, and deficit volume) between January 1980 and December 2013

\begin{tabular}{lllc}
\hline Onset & Duration [month] & No. of drought events & Deficit [mm] \\
\hline Dec-80 & 7 & 1 & 13.45 \\
Nov-81 & 17 & 2 & 14.75 \\
Nov-83 & 18 & 1 & 29.71 \\
Sep-86 & 11 & 3 & 16.32 \\
Dec-87 & 42 & 5 & 9.23 \\
Sep-91 & 17 & 3 & 7.85 \\
Oct-93 & 24 & 4 & 22.56 \\
Oct-99 & 7 & 1 & 8.87 \\
Apr-01 & 30 & 3 & 62.62 \\
Dec-03 & 34 & 2 & 40.01 \\
Feb-07 & 30 & 2 & 59.77 \\
Nov-10 & 23 & 4 & 4.89 \\
\hline
\end{tabular}

propagate to groundwater recharge drought; however, the impact of this drought propagation on the ecosystem, e.g., wetlands, rivers, remains to be studied. The studies in humid climates such as those described in Wossenyeleh et al.
(2021), indicated that drought propagation from meteorological to groundwater had an impact on wetlands. Moreover, the study from Bisrat and Berhanu (2019) in the semiarid climate in Ethiopia also shows that drought propagation could explain water scarcity in the rivers through drought propagation in the hydrological cycle.

In this study, the unsaturated soil zone's delay effect is only incorporated in the calibration but not in the whole groundwater drought analysis. Accordingly, the 1.7-month average lag investigated in the drought of propagation analysis is too short to see the effect of drought on the water table. Therefore, seeing the impact of meteorological drought propagation on groundwater level and discharge might take longer than the investigated lag time of 1.7 months.

\section{Conclusion}

In this study, drought propagation in the hydrological cycle from meteorological drought to groundwater recharge drought in a semiarid climate context was investigated. Meteorological drought and groundwater drought were determined separately
Table 4 Onset of SGI groundwater recharge drought between January 1980 and September 2013 and number of meteorological droughts (SPI-1) ranging from moderate to extreme severity before the onset of groundwater recharge drought with lag time

\begin{tabular}{llll}
\hline Onset & $\begin{array}{l}\text { No. of SGI } \\
\text { drought events }\end{array}$ & $\begin{array}{l}\text { No. of meteorological droughts (SPI-1) before the onset of } \\
\text { groundwater drought on recharge }\end{array}$ & $\begin{array}{l}\text { Lag time } \\
{[\text { month] }}\end{array}$ \\
\hline Nov-80 & 4 & $5(1 \mathrm{~S}, 4 \mathrm{Mo})$ & 5 \\
Jan-84 & 5 & $4(1 \mathrm{E}, 1 \mathrm{~S}, 2 \mathrm{Mo})$ & 7 \\
Dec-85 & 4 & $2(2 \mathrm{Mo})$ & 4 \\
Dec-87 & 3 & $2(2 \mathrm{Mo})$ & 7 \\
Nov-90 & 2 & $2(2 \mathrm{Mo})$ & 2 \\
Nov-93 & 4 & $5(1 \mathrm{~S}, 4 \mathrm{Mo})$ & 7 \\
Feb-97 & 5 & $2(1 \mathrm{~S}, 3 \mathrm{Mo})$ & 8 \\
Jan-03 & 3 & $6(2 \mathrm{~S}, 4 \mathrm{Mo})$ & 9 \\
Dec-05 & 2 & $2(2 \mathrm{Mo})$ & 10 \\
Nov-07 & 5 & $7(1 \mathrm{~S}, 6 \mathrm{Mo})$ & 5 \\
Dec-11 & 3 & $1(1 \mathrm{Mo})$ & 4 \\
\hline
\end{tabular}

$E$ extreme; $S$ severe; $M o$ moderate 

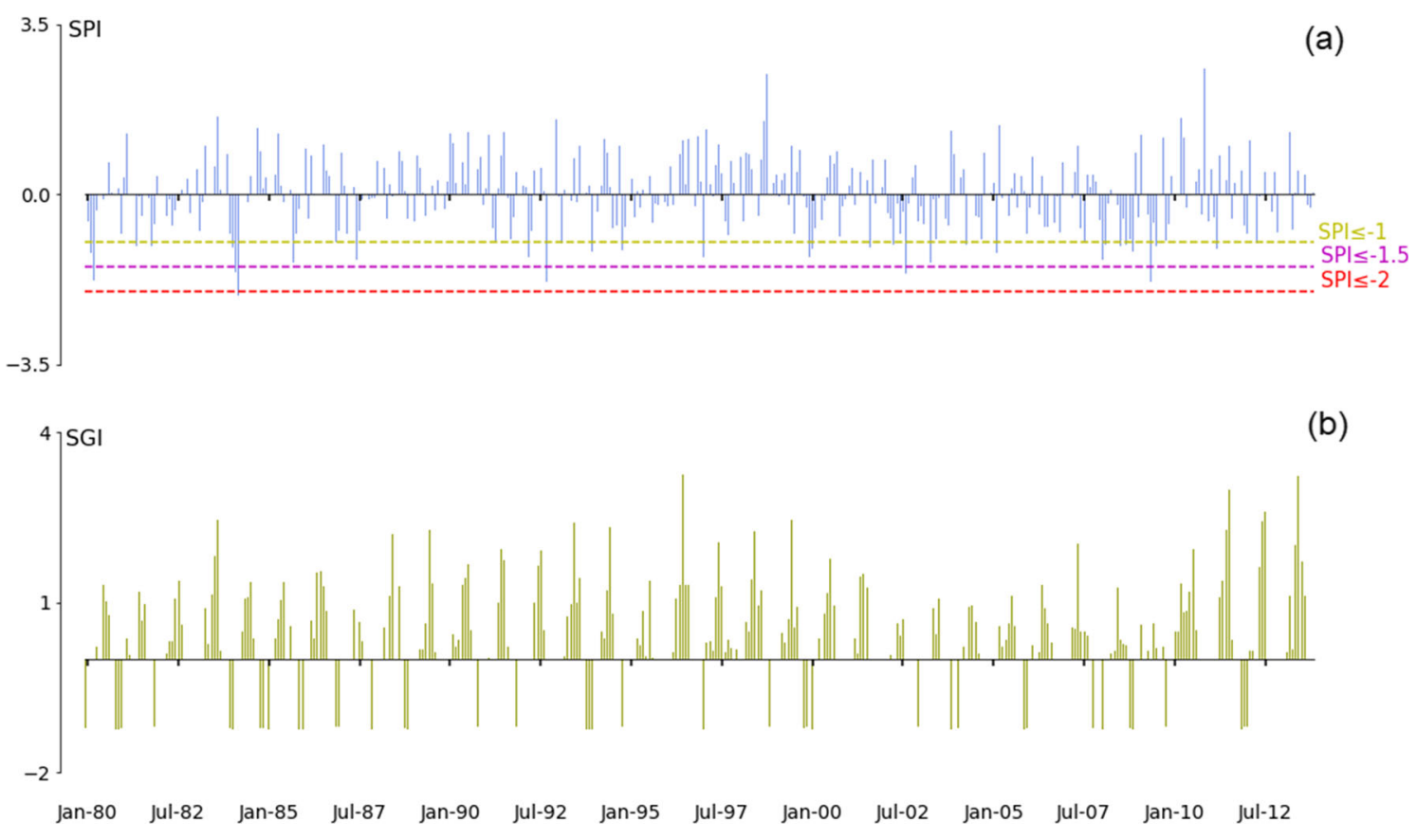

(b)

Fig. 14 Comparison of meteorological drought severity and groundwater recharge drought a monthly SPI value and $\mathbf{b}$ groundwater recharge drought using monthly SGI

and compared to analyze drought propagation in the hydrological cycle. Water balance modeling, a variable threshold method and standardize groundwater index were used to assess groundwater recharge drought. Moreover, a standardized meteorological drought index was used to analyze meteorological drought severity. The research was applied in the Bilate River catchment in the Rift Valley basin of Ethiopia.

Temporally and spatially variable long-term groundwater recharge was estimated using the water balance model WetSpass. The model was calibrated using baseflow separated from observed river discharge. As a result, the model gives a good calibration result with a Nash-Sutcliffe efficiency coefficient of 0.69 and a coefficient of determination of 0.86 ; subsequently, the groundwater recharge time series was used for drought analysis.

Meteorological drought analysis in the catchment shows that meteorological drought occurs with different severity ranges, i.e., from no drought to extreme drought. Moreover, the hydrological year of 2007-2008 is identified as a severe drought period. In the same manner, groundwater recharge drought analysis indicated the occurrence of drought in recharge. Major groundwater recharge drought events were identified based on the cumulative deficit volume of groundwater recharge such as the drought from December 2001 to September 2003 with a cumulative deficit recharge of $136 \mathrm{~mm}$.

Meteorological droughts propagate to groundwater recharge. These droughts were observed before every groundwater recharge drought with an average lag time of 1.7 months. Moreover, a combination of meteorological droughts ranging from mild to severe can result in a major groundwater recharge drought - for example, the major groundwater drought between December 2001 and September 2003.

This study shows that a comparison of meteorological drought (SPI) with groundwater drought on recharge (SGI) helps assess the hydrological cycle's drought propagation. It also shows that meteorological drought can propagate to groundwater recharge drought, but not every meteorological drought results in groundwater drought.

Acknowledgements Meteorological data of the study area were obtained from Ethiopia Ministry of Water, Irrigation and Energy. Land use and soil data were collected from Ethiopian Ministry of Agriculture.

Funding This research was supported by a KU Leuven interfaculty council for development cooperation (IRO) $\mathrm{PhD}$ scholarship.

Data availability statement The data that support the findings of this study are available from the corresponding author upon reasonable request.

\section{Declarations}

Conflict of interest The corresponding author states that there is no conflict of interest.

Open Access This article is licensed under a Creative Commons Attribution 4.0 International License, which permits use, sharing, adaptation, distribution and reproduction in any medium or format, as long as you give appropriate credit to the original author(s) and the source, provide a link to the Creative Commons licence, and indicate if changes were made. The images or other third party material in this article are included in the article's Creative Commons licence, unless indicated otherwise in a 
credit line to the material. If material is not included in the article's Creative Commons licence and your intended use is not permitted by statutory regulation or exceeds the permitted use, you will need to obtain permission directly from the copyright holder. To view a copy of this licence, visit http://creativecommons.org/licenses/by/4.0/.

\section{References}

Abdollahi K, Bashir I, Verbeiren B, Harouna M, van Griensven A, Huysmans M, Batelaan O (2017) A distributed monthly water balance model: formulation and application on Black Volta Basin. Environ Earth Sci 76:1-18. https://doi.org/10.1007/s12665-0176512-1

Ayenew T, Demlie M, Wohnlich S (2008) Hydrogeological framework and occurrence of groundwater in the Ethiopian aquifers. J African Earth Sci 52:97-113. https://doi.org/10.1016/j.jafrearsci.2008.06. 006

Batelaan O, DeSmedt F (2001) WetSpass: a flexible, GIS based, distributed recharge methodology for regional groundwater modelling. In: Proceedings of a symposium held during the Sixth IAHS Scientific Assembly, Maastricht, The Netherlands. IAHS Publ. 269, IAHS, Wallingford, UK, pp 11-17

Batelaan O, De Smedt F (2007) GIS-based recharge estimation by coupling surface-subsurface water balances. J Hydrol 337(3-4):337355. https://doi.org/10.1016/j.jhydrol.2007.02.001

Bekele B, Wu W, Yirsaw E, Negussie W, Alemayehu A (2019) Climate change and its effect on land use change in the Central Rift Valley of Ethiopia. Appl Ecol Environ Res 17:7693-7713. https://doi.org/10. 15666/aeer/1704_76937713

Bisrat E, Berhanu B (2019) Drought in Ethiopia: temporal and spatial characteristics. In: Extreme hydrology and climate variability: monitoring, modelling, adaption and mitigation. Elsevier, Amsterdam, pp 263-274. https://doi.org/10.1016/B978-0-12-815998-9.00021-X

Bloomfield JP, Marchant BP (2013) Analysis of groundwater drought building on the standardised precipitation index approach. Hydrol Earth Syst Sci 17:4769-4787. https://doi.org/10.5194/hess-174769-2013

Chernet T (1993) Hydrogeology of Ethiopia and water resources development. Geological Surveys, Addis Ababa, Ethiopia, 222 pp

Das HP, Kore PA, Jadhav VN (2003) An effective method of identification of drought in kharif season. Mausam 54:909-916

Dereje B, Nedaw D (2019) Groundwater recharge estimation using WetSpass modeling in Upper Bilate Catchment, southern Ethiopia. Momona Ethiop J Sci 11:37. https://doi.org/10.4314/mejs.v11i1.3

Döll P, Fiedler K (2008) Global-scale modeling of groundwater recharge. Hydrol Earth Syst Sci 12:863-885. https://doi.org/10.5194/hess-12863-2008

Edossa DC, Babel MS, Das GA (2010) Drought analysis in the Awash River basin, Ethiopia. Water Resour Manag 24:1441-1460. https:// doi.org/10.1007/s11269-009-9508-0

Edward DC, McKee TB (1997) Characteristics of 20th century drought in the United States at multiple time scales. Colorado State University, Fort Collins, CO

FAO (1998) The digital soil and terrain map of East Africa (Sea). https:// data.review.fao.org/map/catalog/srv/search?createDateYear=1998. Accessed January 2022

Förch G, Althoff I (2009) Water balance modelling in the southern Ethiopian Rift Valley: the example of the Bilate River catchment. Centre for International Capacity Development Series, vol 3, CICD, UniversitätSiegen, Siegen, Germany

Gebremeskel G, Kebede A (2017) Spatial estimation of long-term seasonal and annual groundwater resources: application of WetSpass model in the Werii watershed of the Tekeze River Basin, Ethiopia. Phys Geogr 38:338-359. https://doi.org/10.1080/02723646.2017. 1302791

Gebreyohannes T, De Smedt F, Walraevens K et al (2013) Application of a spatially distributed water balance model for assessing surface water and groundwater resources in the Geba basin, Tigray, Ethiopia. J Hydrol 499:110-123. https://doi.org/10.1016/j.jhydrol. 2013.06.026

Godfrey S, Hailemichael G (2017) Life cycle cost analysis of water supply infrastructure affected by low rainfall in Ethiopia. J Water Sanit Hyg Dev 7:601-610. https://doi.org/10.2166/washdev.2017.026

Kahsay GH, Gebreyohannes T, Gebremedhin MA et al (2019) Spatial groundwater recharge estimation in Raya basin, northern Ethiopia: an approach using GIS based water balance model. Sustain Water Resour Manag 5:961-975. https://doi.org/10.1007/s40899-018$0272-2$

Kebede S (2013) Groundwater in Ethiopia features, numbers and opportunities. Springer Heidelberg, Germany

MacDonald AM, Calow RC, Nicol AL, et al (2001) Ethiopia: water security and drought. Groundwater 48(2):246-256

McKee TB, Doesken NJ, Kleist J (1993) A drought climatology for Europe. In: Proceedings of the 8th conference on applied climatology, Anaheim, California, 17-22 January 1993, pp 179-183

Moloro TL (2018) Spatio-temporal analysis of rainfall variability and meteorological drought: a case study in Bilate River basin, southern Rift Valley, Ethiopia. Int J Environ Sci Nat Resour 14. https://doi. org/10.19080/ijesnr.2018.14.555891

Nasir J, Assefa E, Zeleke T, Gidey E (2021) Meteorological drought in northwestern escarpment of Ethiopian Rift Valley: detection seasonal and spatial trends. Environ Syst Res 10. https://doi.org/10.1186/ s40068-021-00219-3

Pandey RP, Ramasastri KS (2002) Incidence of droughts in different climatic regions. Hydrol Sci J 47:S31-S40. https://doi.org/10. 1080/02626660209493020

Pandey RP, Mishra SK, Singh R, Ramasastri KS (2008) Streamflow drought severity analysis of Betwa River System (India). Water Resour Manag 22:1127-1141. https://doi.org/10.1007/s11269007-9216-6

Peters E (2003) Propagation of drought through groundwater systems. $\mathrm{PhD}$ Thesis, Wageningen University, The Netherlands, $221 \mathrm{pp}$

Ponce VM, Pandey RP, Ercan S (2000) Characterization of drought across climatic spectrum. Hydrol Eng 5:222-224. https://doi.org/ 10.1061/(ASCE)1084-0699(2000)5:2(222)

Schwabe K, Albiac J, Connor JD et al (2013a) Drought in arid and semiarid regions. Springer, Dordrecht, The Netherlands. https://doi.org/ 10.1007/978-94-007-6636-5

Schwabe K, Albiac J, Connor JD, Hassan RM (2013b) Drought in arid and semi-arid regions. In: A multi-disciplinary and cross-country perspective. Springer, Dordrecht, The Netherlands. https://doi.org/ 10.1007/978-94-007-6636-5_20

Seboka Tura F (2017) Climate variability and drought in the past 30 years in Central Rift Valley of Ethiopia. J Nat Sci Res 7:18-26

Stahl K, Hisdal H (2004) Hydroclimatology. In: Tallaksen LM, Van Lanen HAJ (eds) Hydrological drought: processes and estimation methods for streamflow and groundwater, 1st edn. Elsevier, Amsterdam, pp 19-51. https://doi.org/10.1007/1-4020-3266-8_103

Tallaksen LM, Hisdal H, Van Lanen HAJ (2006) Propagation of drought in a groundwater fed catchment, the Pang in the UK. IAHS-AISH Publ. 128-133, IAHS, Wallingford, UK

Tamiru A (2006) Groundwater occurrence in Ethiopia. Addis Ababa University, Addis Ababa, Ethiopia

Teklebirhan A, Dessie N, Tesfamichael G (2012) Groundwater recharge, evapotranspiration and surface runoff estimation using WetSpass modeling method in Illala catchment, northern Ethiopia. Momona Ethiop J Sci 4:96. https://doi.org/10.4314/mejs.v4i2.80119 
Tesfaye Tessema G (2010) Groundwater potential evaluation based on integrated GIS and remote sensing techniques in Bilate River catchment: South Rift Valley of Ethiopia. http://etd.aau.edu.et/handle/ 123456789/7923. Accessed January 2022

Thom HCS (1958) A note on the gamma distribution. Mon Weather Rev 86:117-122. https://doi.org/10.1175/1520-0493(1958)086<0117: $\operatorname{anotgd}>2.0 . \operatorname{co} ; 2$

Thomas EA, Needoba J, Kaberia D et al (2019) Quantifying increased groundwater demand from prolonged drought in the East African Rift Valley. Sci Total Environ 666:1265-1272. https://doi.org/10. 1016/j.scitotenv.2019.02.206

Tilahun K, Merkel BJ (2009) Estimation of groundwater recharge using a GIS-based distributed water balance model in Dire Dawa, Ethiopia. Hydrogeol J 17:1443-1457. https://doi.org/10.1007/s10040-0090455-x

Todmal RS (2019) Droughts and agriculture in the semi-arid region of Maharashtra, western India. Weather Clim Soc 11:741-754. https:// doi.org/10.1175/WCAS-D-18-0131.1

Van Lanen HAJ (2006) Drought propagation through the hydrological cycle. In: Proceedings of the fifth FRIEND world conference about climate variability and change-hydrological impacts, Havana, Cuba, November 2006. IAHS Publ. 308, IAHS, Wallingford, UK, pp 122-127

Van Loon AF (2013) On the propagation of drought how climate and catchment characteristics influence hydrological drought development and recovery. PhD Thesis, Wageningen University, The Netherlands, $195 \mathrm{pp}$

Van Loon AF, Van Lanen HAJ (2012) A process-based typology of hydrological drought. Hydrol Earth Syst Sci 16:1915-1946. https://doi.org/10.5194/hess-16-1915-2012

Vidal JP, Martin E, Franchistéguy L et al (2010) Multilevel and multiscale drought reanalysis over France with the Safran-Isba-
Modcou hydrometeorological suite, Hydrol. Earth Syst. Sci 14: 459-478. https://doi.org/10.5194/hess-14-459-2010

Walker S (2003) The use of agroclimatic zones as a basis for tailored seasonal rainfall forecasts for the cropping systems in the Central Rift Valley of Ethiopia. In: Insights and tools for adaptation: learning from climate variability. In: Insights and Tools for Adaptation: Learning from Climate Variability conference, Washington, DC, Nov 2003, 8 pp. https://doi.org/10.13140/2.1.1709.1522

Willems P (2009) A time series tool to support the multi-criteria performance evaluation of rainfall-runoff models. Environ Model Softw 24:311-321. https://doi.org/10.1016/j.envsoft.2008.09.005

WMO (1975) Drought and agriculture: report of the CaGm Working Group on the Assessment of Drought. WMO, Geneva, Switzerland

Wossenyeleh BK, Verbeiren B, Diels J, Huysmans M (2020) Vadose zone lag time effect on groundwater drought in a temperate climate. Water 12:2123. https://doi.org/10.3390/w12082123

Wossenyeleh BK, Worku KA, Verbeiren B, Huysmans M (2021) Drought propagation and its impact on groundwater hydrology of wetlands: a case study on the Doode Bemde Nature Reserve (Belgium). Nat Hazards Earth Syst Sci 21:39-51. https://doi.org/ 10.5194/nhess-21-39-2021

Yevjevich V (1967) An objective approach to definitions and investigations of continental hydrologic droughts. Hydrology Papers, Colorado State University, vol 23, Fort Collins, CO, 25 pp

Zewdie A (1994) Water resources development in Ethiopia: an evaluation of present experience and future planning concepts. Ithaca, Reading, UK

Publisher's note Springer Nature remains neutral with regard to jurisdictional claims in published maps and institutional affiliations. 